\title{
Morphometric Evaluation of Phenotypic Groups of Creole Cattle of Southern Ecuador
}

\author{
Edgar Lenin Aguirre-Riofrio*(D), Rodrigo Medardo Abad-Guamán and \\ Melania de Lourdes Uchuari-Pauta ${ }^{\mathbb{D}}$
}

Facultad Agropecuaria, Carrera de Medicina Veterinaria y Zootecnia, Universidad Nacional de Loja-Ecuador, Loja 110103, Ecuador; rodrigo.abad@unl.edu.ec (R.M.A.-G.); melania_lourdes@yahoo.es (M.d.L.U.-P.)

* Correspondence: edgar.aguirre@unl.edu.ec or leninaguirrer@yahoo.es

Received: 12 July 2019; Accepted: 30 September 2019; Published: 20 November 2019

\begin{abstract}
The breeding of creole cattle from the southern region of Ecuador, also known as Criollo Lojano, is a source of economic support and work for the communities located in the remote areas of the Andes mountains in this region. These cattle are grouped into four biotypes based on their phenotypic characteristics: Negro Lojano, Encerado, Colorado, and Cajamarca or Pintado. This study analyzes the morphometric variability of these creole cattle using least squares means (LSM) and restricted maximum likelihood Restricted Maximum Likelihood (REML) variance components. The evaluation parameters used to characterize these cattle were live weight plus 15 morphometric characteristics and nine morphometric indexes. The measurements came from 151 adult animals (28 male and 123 females). With the exception of Height at Withers $(P=0.06)$, the other morphometric characteristics do not show significant difference among these creole biotypes. Sexual dimorphism was found in live weight, thoracic circumference, height at withers, chest width, length of thorax, length of body, depth of thorax, depth of abdomen, length of head, and length of horns $(P<0.05)$. The adult Creole Lojano has an average live weight of $288 \pm 12.9 \mathrm{~kg}$ (mean \pm standard error), The Cephalic index is 45.6, the Corporal index is 115.9, the Pelvic index is 90.5, the Thoracic index is 58.3, the Proportionality index is 62.6, the Thoracic Capacity index is 2.1, the Lower Leg-Thoracic index is 9.9, the Transverse Pelvic index is 34.7, and the Pelvic Length index is 38.4. This creole bovine breed presents 4 biotypes that are similar; there are differences in the analysis with respect to sex (males are higher in 10 of the 16 characteristics analyzed); and on the basis of the indexes, this animal is small, has a triangular head, is longilinear with a long and narrow hip. It is a dual-purpose milk type with the exception of the Colorado biotype which is a dual purpose meat type.
\end{abstract}

Keywords: morphometric; index; coat color; creole bovine; Southern Ecuador

\section{Introduction}

When Sebastian de Benalcázar arrived in 1534 to Ecuador for the conquest of Kingdom of Quito, he introduced the first Bos taurus cattle [1]. The descendants of these animals have had a long process of more than five centuries of adaptation to different climates and environments. This is especially true in the high Andean area with its irregular topography. Since this time, these Creole cattle (naturalized from their Iberian source) have occupied Ecuador. Recently they have exposed to disorderly crossbreeding which has produced a process of absorption of Creole animals. As a result, the number of this Creole population has been decreasing drastically. In spite of this, the existence of small and heterogeneous nuclei of Creole cattle is still reported in some remote places, such as the Southern Region of Ecuador (SRE) bordering on the north of Perú [2]. Due to their phenotypic and genotypic characteristics they have managed to survive and develop in these complex environments, acquiring their own characteristics that have allowed them to adapt and thrive in this hard habitat. 
These cattle play an important role in the life of marginal small farmers of the SRE, constituting a source of subsistence, work and environmental welfare. They provide milk, meat, cash from the sale of animals, animal traction, and the use of forages in these areas. These products and services all benefit these geographically remote regions where agricultural mechanization is not possible. The cattle reduce the risk of forest fires which is otherwise enhanced due to unconsumed dry vegetation. The breeding of other types of cattle in these environments is unsustainable.

Genetic analysis of these cattle through molecular markers [2] showed that this population can be considered as a breed. This population shows the greatest degree of genetic similarity $(>0.10)$ to Iberian breeds such as Berrenda Colorada, Pajuna, Negra Andaluza and Canaria. In the SRE, four biotypes of these cattle are found: Negro Lojano, Encerado, Colorado, and Cajamarca. These four have a low interpopulation variability $\left(\mathrm{G}_{\mathrm{ST}}=0,045 \pm 0,028\right.$ y $\left.\mathrm{F}_{\mathrm{ST}}=0,0008\right)$, therefore they are not genetically different from each other. The object of this study was to determine if there is morphometric variability between these biotypes by zoometric indexes and to characterize the phenotype of this cattle breed.

\section{Materials and Methods}

The present study was conducted in the Province of Loja located at $3^{\circ} 49^{\prime} 59^{\prime \prime} \mathrm{S}$ and $80^{\circ} 04^{\prime} 01^{\prime \prime} \mathrm{W}$, in the Andean Highlands of Ecuador which borders the north of Perú. The habitat of the creole cattle is between $600 \mathrm{~m}$ and $2000 \mathrm{~m}$ above sea level, with a temperature between $15^{\circ} \mathrm{C}$ and $25^{\circ} \mathrm{C}$. Due to its irregular relief there are a variety of mesoclimates ranging from tropical semi-desert in the low parts to temperate in the high parts (Figure 1).

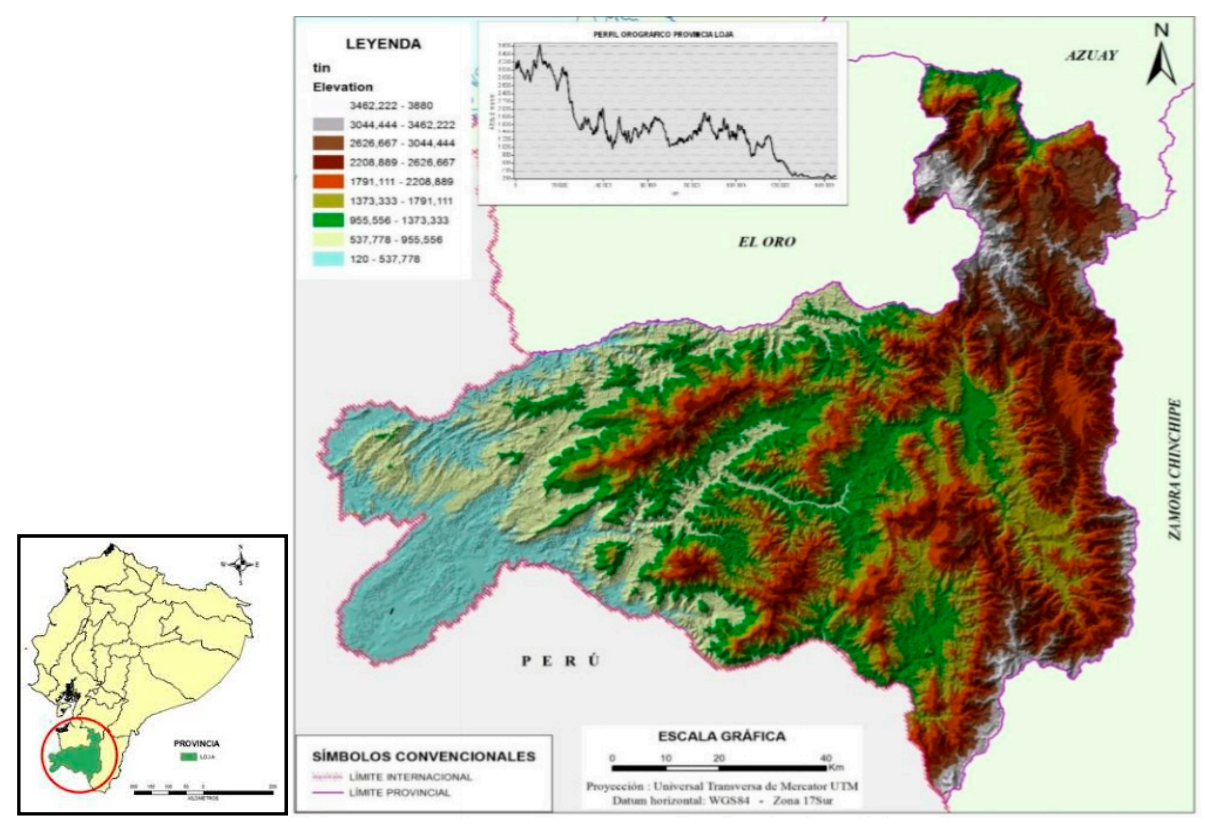

Figure 1. Orographic map of province of Loja-Ecuador.

The measurements came from 151 adult animals (28 males and 123 females) of different ages. (This study was approved by the Bioethics Committee on Animal Research and Veterinary Education in October 8, 2018, Certification number: $\mathrm{N}^{\circ} 03-2018$.) They were grouped by their coat color into four commonly accepted and traditional biotypes: Negro Lojano, Encerado, Colorado and Cajamarca (also called Pintado). Considered as fixed effects were: biotype, sex, and age as covariate. These were used to determine if they were associated with differences in the characteristics analyzed. Measurements include adult live weight plus 15 morphometric characteristics: Thoracic Circumference (TC), Height at Withers (H), Chest Width (CW), Thoracic Length (TL), Body Length (BL), Thoracic Depth (TD), Abdomen Depth (AD), Hip Length (HL), Anterior Hip Width (AHW), Posterior Hip Width (PHW), length of Canon (LC), Circumference of Canon (PC), Head width (HeW), Head length (HeL) and length 
of Horns (LH). Nine morphometric indexes were also evaluated (Table 1): Cephalic, length index, Pelvic, Thoracic, Thoracic Capacity, Lower Leg-thoracic Circumference, Lower Leg-Chest Width, Transverse Pelvic and Longitudinal Pelvic.

Table 1. Zoometric indexes determined in the adult Criollo Lojano cattle.

\begin{tabular}{|c|c|c|}
\hline Index Type & Index & Formula \\
\hline \multirow{5}{*}{ Ethnological } & Cephalic (Ce) & $\mathrm{ICe}=($ head width $/$ head length $) \times 100$ \\
\hline & Corporal (Co) & ICo $=($ body length $/$ thoracic circumference $) \times 100$ \\
\hline & Thoracic $(\mathrm{T})$ & IT $=($ chest width/thoracic depth $) \times 100$ \\
\hline & Pelvic (Pe) & $\mathrm{IPe}=($ anterior hip width $/$ hip length $) \times 100$ \\
\hline & Thoracic Capacity (TC) & ITC $=$ thoracic perimeter ${ }^{2} /($ height $\times 100)$ \\
\hline \multirow[t]{2}{*}{ Productive aptitude (milk) } & $\begin{array}{l}\text { Lower Leg-Thoracic } \\
\text { Circumference (LLTC) }\end{array}$ & $\begin{aligned} \text { ILLTC }= & (\text { circumference of canon/ thoracic } \\
& \text { circumference }) \times 100\end{aligned}$ \\
\hline & Lower Leg-Chest Width (LLCW) & ILLCW $=($ circumference of canon/chest width $) \times 100$ \\
\hline \multirow{2}{*}{ Productive aptitude (meat) } & Transverse Pelvic (TP) & ITP $=($ anterior hip width $/$ height $) \times 100$ \\
\hline & Longitudinal Pelvic (PL) & ILP $=($ hip length /height $) \times 100$ \\
\hline
\end{tabular}

Live weight and the morphometric characteristics were analyzed using Mixed procedure of Least Squared Means (LSM) and by variance components by Restricted Maximum Likelihood (REML), from the morphometric measurements the zoometric indexes were determined [3-5].

\section{Results}

The results of the present study are in Table 2 and Table S1. The Criollo Lojano cattle have an adult live weight of $288 \pm 13.5 \mathrm{~kg}$, and there is no significant difference between the four biotypes, being slightly lighter in the Cajamarca biotype and the heaviest in the Encerado with $279 \pm 13.1$ and $293 \pm 12.9 \mathrm{~kg}$ respectively. Fourteen of the 15 morphometric characteristics analyzed did not present statistical differences between the four biotypes (Figure 2); only the height tends to show differences $(P=0.06)$. The Criollo Lojano has a small stature $(109 \pm 1.6 \mathrm{~cm})$, the Colorado is the shortest of the four, $(107 \pm 2 \mathrm{~cm})$ and the Negro and Cajamarca biotypes are the tallest $111 \pm 1.5 \mathrm{~cm}$. 
Table 2. Live weight and morphometric characteristics from the four biotypes of Criollo Lojano bovine (mean \pm standard error).

\begin{tabular}{|c|c|c|c|c|c|}
\hline \multirow{2}{*}{ Characteristic } & \multicolumn{4}{|c|}{ Biotype } & \multirow{2}{*}{ Mean } \\
\hline & Negro & Encerado & Colorado & Cajamarca & \\
\hline Live weight (Kg) & $290 \pm 12.3$ & $293 \pm 12.9$ & $291 \pm 15.6$ & $279 \pm 13.1$ & $288 \pm 13.5$ \\
\hline Thoracic circumference $(\mathrm{cm})$ & $151 \pm 2.6$ & $149 \pm 2.8$ & $149 \pm 3.4$ & $150 \pm 2.8$ & $150 \pm 2.9$ \\
\hline${ }^{*}$ Height $(\mathrm{cm})$ & $111 \pm 1.2$ & $109 \pm 1.6$ & $107 \pm 2.0$ & $111 \pm 1.5$ & $109 \pm 1.6$ \\
\hline Chest width (cm) & $34 \pm 0.8$ & $34 \pm 0.9$ & $33 \pm 1.1$ & $34 \pm 0.9$ & $34 \pm 0.9$ \\
\hline Thoracic length $(\mathrm{cm})$ & $61 \pm 1.3$ & $62 \pm 1.3$ & $60 \pm 1.6$ & $62 \pm 1.4$ & $61 \pm 1.4$ \\
\hline Body length (cm) & $177 \pm 2.4$ & $174 \pm 3.2$ & $172 \pm 3.9$ & $178 \pm 2.9$ & $175 \pm 3.1$ \\
\hline Thoracic depth (cm) & $58 \pm 1.3$ & $57 \pm 1.4$ & $57 \pm 1.7$ & $57 \pm 1.4$ & $57 \pm 1.4$ \\
\hline Abdomen depth (cm) & $60 \pm 1.4$ & $59 \pm 1.4$ & $58 \pm 1.7$ & $60 \pm 1.4$ & $59 \pm 1.5$ \\
\hline Hip length (cm) & $43 \pm 0.6$ & $42 \pm 0.8$ & $42 \pm 0.9$ & $43 \pm 0.7$ & $42 \pm 0.7$ \\
\hline Anterior hip width (cm) & $40 \pm 0.9$ & $40 \pm 0.9$ & $38 \pm 1.2$ & $40 \pm 1.0$ & $39 \pm 1.0$ \\
\hline Posterior hip width $(\mathrm{cm})$ & $16 \pm 0.5$ & $16 \pm 0.5$ & $15 \pm 0.6$ & $15 \pm 0.5$ & $16 \pm 0.5$ \\
\hline Length of canon (cm) & $17 \pm 0.2$ & $17 \pm 0.3$ & $17 \pm 0.3$ & $17 \pm 0.3$ & $17 \pm 0.3$ \\
\hline Circumference of canon $(\mathrm{cm})$ & $15 \pm 0.3$ & $15 \pm 0.3$ & $15 \pm 0.4$ & $15 \pm 0.3$ & $15 \pm 0.3$ \\
\hline Head width $(\mathrm{cm})$ & $21 \pm 0.3$ & $20 \pm 0.3$ & $21 \pm 0.4$ & $21 \pm 0.3$ & $21 \pm 0.3$ \\
\hline Head length (cm) & $46 \pm 0.6$ & $46 \pm 0.8$ & $45 \pm 1.0$ & $46 \pm 0.7$ & $46 \pm 0.8$ \\
\hline Length of horns $(\mathrm{cm})$ & $21 \pm 1.1$ & $21 \pm 1.5$ & $22 \pm 1.8$ & $21 \pm 1.4$ & $21 \pm 1.4$ \\
\hline
\end{tabular}

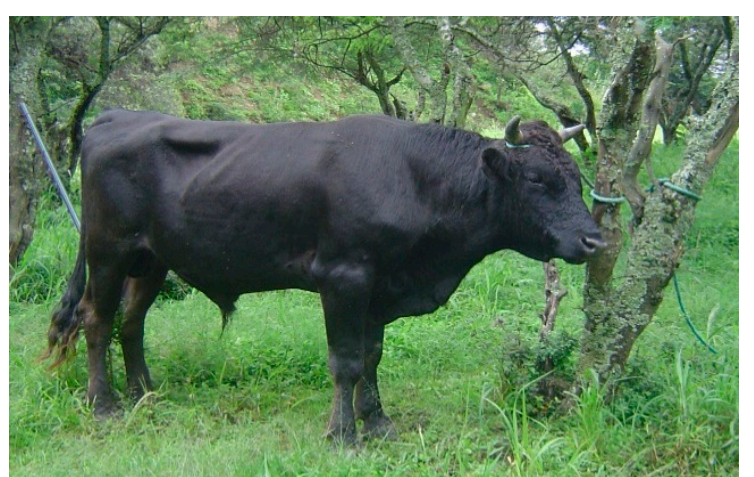

Biotype "Negro Lojano"

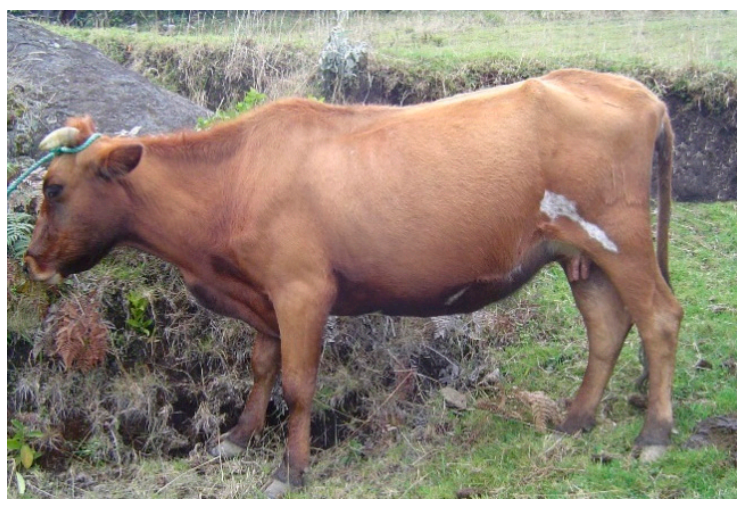

Biotype "Colorado"

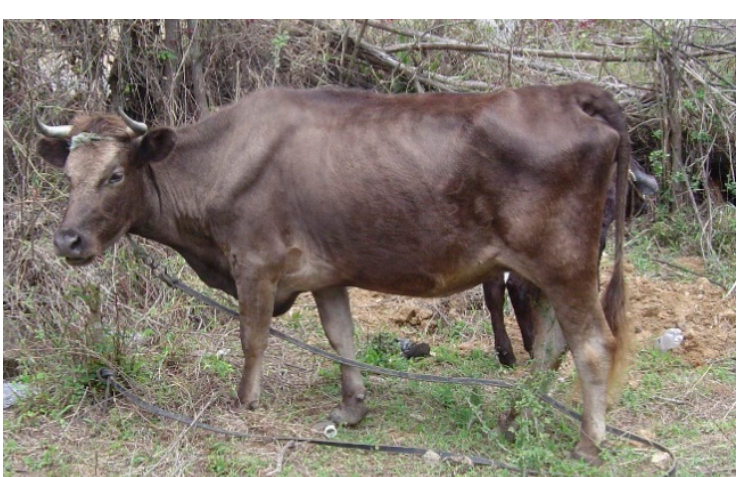

Biotype "Encerado"

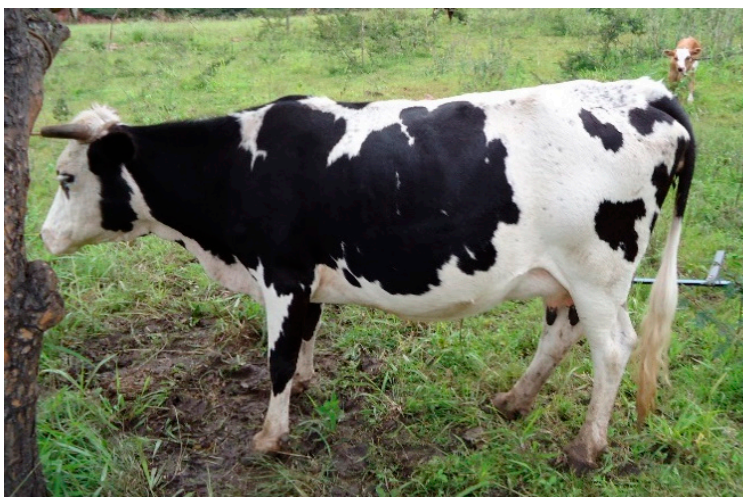

Biotype "Pintado o Cajamarca"

Figure 2. Criollo Lojano of all four biotypes.

Within all four biotypes of adult Criollo Lojano bovine (Table 3 and Table S1), the males are heavier $(302 \pm 13.6 \mathrm{~kg})$ than the females $(275 \pm 9.9 \mathrm{~kg})$, and of the 15 characteristics analyzed, two thirds have a sexual dimorphism in which males have higher values than females. 
Table 3. Live weight and morphometric characteristics considering the sex of adult Criollo Lojano bovine (mean \pm standard error).

\begin{tabular}{|c|c|c|c|}
\hline \multirow{2}{*}{ Characteristic } & \multicolumn{2}{|c|}{ Sex } & \multirow{2}{*}{$\operatorname{Pr}>|t|$} \\
\hline & Male & Female & \\
\hline Live weight (Kg) & $302^{\mathrm{a}} \pm 13.6$ & $275^{b} \pm 9.9$ & 0.048 \\
\hline Thoracic circumference $(\mathrm{cm})$ & $153^{\mathrm{a}} \pm 3.0$ & $147^{b} \pm 2.0$ & 0.035 \\
\hline Height $(\mathrm{cm})$ & $111^{\mathrm{a}} \pm 1.7$ & $107^{\mathrm{b}} \pm 0.9$ & 0.042 \\
\hline Chest width $(\mathrm{cm})$ & $35^{\mathrm{a}} \pm 0.9$ & $32^{b} \pm 0.7$ & 0.002 \\
\hline Thoracic length $(\mathrm{cm})$ & $63^{\mathrm{a}} \pm 1.4$ & $60^{\mathrm{b}} \pm 1.0$ & 0.046 \\
\hline Body length $(\mathrm{cm})$ & $179 \pm 3.3$ & $172 \pm 1.7$ & 0.060 \\
\hline Thoracic depth (cm) & $59^{\mathrm{a}} \pm 1.5$ & $55^{\mathrm{b}} \pm 1.1$ & 0.003 \\
\hline Abdomen depth $(\mathrm{cm})$ & $61^{\mathrm{a}} \pm 1.5$ & $57^{b} \pm 1.1$ & 0.005 \\
\hline Hip length $(\mathrm{cm})$ & $43 \pm 0.8$ & $42 \pm 0.4$ & 0.064 \\
\hline Anterior hip width (cm) & $39 \pm 1.0$ & $39 \pm 0.7$ & 0.634 \\
\hline Posterior hip width $(\mathrm{cm})$ & $15 \pm 1.7$ & $16 \pm 1.7$ & 0.432 \\
\hline Length of canon (cm) & $17 \pm 0.3$ & $17 \pm 0.2$ & 0.884 \\
\hline Circumference of canon $(\mathrm{cm})$ & $16^{\mathrm{a}} \pm 0.3$ & $14^{\mathrm{b}} \pm 0.2$ & $<0.001$ \\
\hline Head width $(\mathrm{cm})$ & $21^{\mathrm{a}} \pm 0.4$ & $20^{\mathrm{b}} \pm 0.2$ & $<0.001$ \\
\hline Head length $(\mathrm{cm})$ & $47 \pm 0.8$ & $45 \pm 0.4$ & 0.061 \\
\hline Length of horns $(\mathrm{cm})$ & $23^{a} \pm 1.5$ & $19^{b} \pm 0.8$ & 0.050 \\
\hline
\end{tabular}

The zoometric indexes (Table 4) reveal that the cattle are dolichocephalic with head longer than wide, and are also longilinear with a tendency more to milk production than to meat production. The rump is almost square with slight predominance of the length over the width. The ITC value (2.1), shows the animals to be a dual-purpose type, although the ILLTC (10.0) is more consistent with dairy type. Among the four, the Negro Lojano biotype tends to be finer (9.9). The ILLTC is related to the strength of animal [6], and the value (44.1) is consistent with cattle of dual purpose type with a broad chest and strong limbs that allow it to move easily in extensive management systems in the environment of the mountainous area of the Andes. ITP (35.8) and ILP (38.5), indicate a very slight tendency to develop muscle mass in the most valuable cutting area such as the posterior regions.

Table 4. Zoometric indexes from Criollo Lojano bovine.

\begin{tabular}{cccccc}
\hline \multirow{2}{*}{ Index } & \multicolumn{5}{c}{ Biotype } \\
\cline { 2 - 6 } & Negro & Encerado & Colorado & Cajamarca & General \\
\hline Cephalic (ICe) & 45.7 & 43.5 & 46.7 & 45.7 & 45.7 \\
\hline Corporal (ICo) & 117.2 & 116.8 & 115.4 & 118.7 & 116.7 \\
\hline Thoracic (IT) & 58.6 & 59.6 & 57.9 & 59.6 & 59.6 \\
\hline Pelvic (IPe) & 93.0 & 95.2 & 90.5 & 93.0 & 92.9 \\
\hline Thoracic Capacity (ITC) & 2.1 & 2.0 & 2.1 & 2.0 & 2.1 \\
\hline Indexes related to Dairy Type & & & & \\
\hline Lower Leg-thoracic circumference(ILLTC) & 9.9 & 10.1 & 10.1 & 10.0 & 10.0 \\
\hline Lower Leg-chest Width (ILLCW) & 44.1 & 44.1 & 45.5 & 44.1 & 44.1 \\
\hline Indexes related to Beef or Meat Type & & & & & 35.8 \\
\hline Transverse Pelvic (ITP) & 36.0 & 36.7 & 35.5 & 36.0 & 38.5 \\
\hline Longitudinal Pelvic (ILP) & 38.7 & 38.5 & 39.3 & 38.7 & \\
\hline
\end{tabular}

\section{Discussion}

The Criollo Lojano is a small animal with low weight compared to other creole populations such as the Criollo from Azuay-Ecuador with its weight and height of $339.5 \mathrm{~kg}$ and $121 \mathrm{~cm}$, respectively [6], 
the Criollo Manabita-Ecuador a weight and height of $456 \mathrm{~kg}$ and $132 \mathrm{~cm}$ [7], while the Criollo Limonero of Venezuela has a live weight of $403.8 \mathrm{~kg}$ and height of $124 \mathrm{~cm}$ [7]. Comparing the weight and height with the Chinampo cattle of Mexico [8] indicates that the Criollo Lojano is slightly smaller $(109 \mathrm{~cm}$ vs. $117 \mathrm{~cm}$ ) but heavier ( $288 \mathrm{~kg}$ vs. $255 \mathrm{~kg}$ ). The thoracic perimeter is similar between these cattle, but smaller than that in other Creole populations such as the Pirenaico [9], Lucerna [10], Pantaneiro [11], and Limonero [5].

The width of chest denotes strength, and in the Criollo Lojano is reduced $(34 \mathrm{~cm})$ in comparison to the other creole cattle, such as those in the Province of Azuay $(39.6 \mathrm{~cm})$ [6] and the Criollo Manabita $(56 \mathrm{~cm})$ [7]. Body length is consistent with a longilinear animal that surpasses the measurements obtained by Pirenaico $(139 \mathrm{~cm})$, Lucerna $(151-167 \mathrm{~cm})$, Pantaneiro $(138-159 \mathrm{~cm})$, Chinampo $(139 \mathrm{~cm})$, Limonero $(130 \mathrm{~cm})$ and Manabita $(167 \mathrm{~cm})$ [5,7-11]. The thoracic depth of Criollo Lojano is similar to the Pirenaico [9], but is less deep than the Pantaneiro $(64-73 \mathrm{~cm})$ of [11], the Bruna dels Pirineus $(72 \mathrm{~cm})$ [12] or the Criollo of Azuay $(80 \mathrm{~cm})$ [6].

The Criollo Lojano has a slightly long and wide rump which allows calving ease and good potential for muscle mass. Its rump length is higher than Limonero cattle $(38 \mathrm{~cm})$ but slightly lower than other cattle breeds such as Criollo Manabita $(44 \mathrm{~cm})$, Pirenaico and Criollo Province of Azuay $(46 \mathrm{~cm})$, Pantaneiro $(47-53 \mathrm{~cm})$, Chinampo $(45 \mathrm{~cm})$. The width of the anterior rump is similar to that of Pirenaico cattle $(40 \mathrm{~cm})$ of [11], but lower than the Pantaneiro and Criollo Manabita $(45 \mathrm{~cm})[7,11]$. The dimensions of the width posterior rump and length of canon are similar between the Criollo Lojano and Criollo of the Province of Azuay; as for the circumference of the canon $(15 \mathrm{~cm})$, it is thin and tends to be milk-type, compared with those of the Criollo cattle of the Province of Azuay, Criollo Manabita and Limonero with circumferences between $17 \mathrm{~cm}$ and $17.8 \mathrm{~cm}$ or the Pirenaica and Bruna dels Pirineus with a canon circumference between $20 \mathrm{~cm}$ and $21.8 \mathrm{~cm}$, respectively. The dimensions of the head in terms of width is similar to the rest of the Creole populations studied, varying in length, and being slightly shorter $(46 \mathrm{~cm})$ than the Limonero, Criollo Manabita and Criollo of the Province of Azuay (48 to $49 \mathrm{~cm}$ ). The horns of the Criollo Lojano vary in their form in the different biotypes. The Negro and Encerado have proceros type horns, with orthoceros type in the Colorado and Cajamarca. The horns $(21 \mathrm{~cm})$ are slightly shorter than the bovines of the Province of Azuay $(24.5 \mathrm{~cm})$ and the Chinampo of Mexico $(27 \mathrm{~cm})$.

The indexes for the Criollo Lojano, and specifically the ICe (45.7), reveal it to be a dolichocephalic animal. Similar values were obtained in the Criollo Limonero (46.3), Criollo Manabita (45.2) and Criollo of the Province of Azuay (45.5), while lower values (longer head) were found in the Colombian Casanare (40) and the Barroso Salmeco of Guatemala with $33.4[13,14]$. The ICo $(116.7)$ is larger compared with other Creole populations (Casanare, Limonero, Barroso, Criollo of the Province of Azuay) due to its long body and reduced thoracic capacity, placing it as longilineal animal of dual-purpose type milk, also corroborated in the ITo (59.6). Lower values indicate a greater tendency to dairy type. Similar values were obtained in the Bruna dels Pirineus (59.4) [12], in the Barroso of Guatemala (57.6) [14], while high values occurred in the Colombian Limonero [5] and in the Criollo Manabita (73) [7]. The ITC (2.1) is similar to the values obtained in other creole breeds. Lower values indicate a tall light animal as is the case in the Bruna dels Pirineus (1.9). The IPe (93) indicates that the rump of the Criollo Lojano is slightly longer than wide, a characteristic shared with the Bruna dels Pirineus (89.6) and the Barroso Salmeco (87.2) while the Criollo of the Province of Azuay (99.5) and the Criollo Manabita (103) have an almost square rump. In the Limonero cattle this index reaches a value of 154 where the width predominates over the length of the rump. The ITP (35.8) and ILP (38.5), are within the ranges indicated by other [15] (p. 171-196) and [15] (p. 83-101). They indicate that the ITP must be higher than 33 and the ILP must not be higher than 37. The Criollo Lojano has a broad and long rump, in contrast to the Criollo Limonero with a broad but short rump (ITP: 47.5 and ILP: 30.6) [5]. The milk fitness index, the ILLTC [10], indicates that the Criollo Lojano is an animal of fine skeleton and dairy type. The Negro biotype (9.9) is the thinnest of them all. Higher values show animals more of meat than dairy type [12], and this is corroborated by the work [6], where diverse populations of Holstein 
and Jersey presented ILLTC below 10; the ILLTC (44.1), indicates the strength of the extremities in relation to the body mass they support [12], lower values of this index relate to an animal with a meat tendency and higher values to a milk tendency, the Criollo Lojano presents values similar to the Criollo of the Province of Azuay (43.3), superior to those obtained in the Criollo Limonero (20.3) and Criollo Manabita (35.5), but slightly lower than Bruna dels Pirineus (52.5) and Barroso Salmeco (54.3).

\section{Conclusions}

The four biotypes of the Criollo Lojano bovine are morphometrically similar, with sexual dimorphism in favor of the males in 10 of the 16 characteristics studied. The zoometric indexes define the breed as one of small stature, lightweight, triangular head form, longilinear and rump slightly longer than wide. It is an animal of dual-purpose type milk with the exception of the biotype Colorado which is dual purpose with more tendency to meat production.

Supplementary Materials: The following are available online at http://www.mdpi.com/1424-2818/11/12/221/s1. Table S1: Least Squared Means and Mean difference of Morphometric characteristics from bovine creole of Southern Ecuador for the biotype and sex.

Author Contributions: Conceptualization, E.L.A.-R.; methodology, E.L.A.-R.; formal analysis, R.M.A.-G. and E.L.A.-R.; writing—original draft preparation, E.L.A.-R.; writing—review and editing, M.d.L.U.-P.

Funding: This research received no external funding.

Acknowledgments: The authors thank all the breeders and technicians of the Province of Loja (South of Ecuador) for collaboration on this research project.

Conflicts of Interest: The authors declare no conflict of interest.

\section{References}

1. Lucena, S.M. Sebastian de Belalcázar; Quórum: Madrid, Spain, 1987.

2. Aguirre-Riofrio, L.; Apolo, G.; Chalco, L.; Martínez, A. Caracterización Genética de La Población Bovina Criolla de La Región Sur Del Ecuador y Su Relación Genética Con Otras Razas Bovinas. Anim. Genet. Resour. Génét. Anim. Genét. Anim. 2014, 54, 93-101. [CrossRef]

3. Dubuc, M.W. Zebuinos y Azebuados: Bos Indicus y Taurus Indicus, 4th ed.; Ediciones Dumar: Caracas, Venezuela, 1991.

4. Martinez, R.D.; Fernandez, E.N.; Rumiano, F.J.; Pereyra, A.M. Medidas Zoométricas de Conformación Corporal en Bovinos Criollos Argentino. Available online: http://www.sian.inia.gob.ve/revistas_ci/ ZootecniaTropical/zt1602/texto/notatecnica2.htm (accessed on 19 June 2019).

5. Contreras, G.; Chirinos, Z.; Zambrano, S.; Molero, E.; Páez, A. Caracterización morfológica e índices zoométricos de vacas Criollo Limonero de Venezuela. Rev. Fac. Agron. Univ. Zulia 2011, 28, 91-103.

6. Ramones, M.A.; Zhunio, L.E. Caracterización Morfométrica e Índices Zoométricos de Los Grupos Raciales Bovinos Existentes en Los Cantones Occidentales de La Provincia del Azuay. Ph.D. Thesis, Universidad de Cuenca, Cuenca, Ecuador, 2017.

7. Cevallos, F.O.; Barba, C.; Delgado, J.V.; González, A.; Perea, J. Caracterización zoométrica y morfológica del ganado Criollo de Manabí (Ecuador). Rev. Cient. 2016, 26, 313-322.

8. Espinoza, J.L.; Guevara, J.A.; Palacios, A. Caracterización morfométrica y faneróptica del bovino criollo chinampo de México. Arch. Zootec. 2009, 58, 277-279.

9. Pastor, F.; Picot, A.; Quintin, F.; Ruiz, M.; Sevilla, E.; Vijil, E. Características Zoométricas de La Raza Bovina Pirenaica En Función de Su Origen Geográfico. Arch. Zootec. 2000, 49, $223-227$.

10. Mahecha, L.; Angulo, J.; Manrique, L.P. Estudio bovinométrico y relaciones entre medidas corporales y el peso vivo en la raza Lucerna. Rev. Colomb. Cienc. Рecu. 2002, 15, 9.

11. Abreu, U.; Santos, S.; Sereno, J.; Comastri-filho, J.; Ravanelli, L. Caracterización Morfométrica de Los Bovinos Pantaneiro Del Núcleo de Conservación in Situ de Nhumirim. Arch. Zootec. 2005, 54, 211-216.

12. Parés, L. Índices de Interés Funcional En La Raza Bovina “Bruna Dels Pirineus". REDVET 2007, 8, 1-9.

13. Salamanca, C.A.; Crosby, G.R. Comparación de Índices Zoométricos En Dos Núcleos de Bovinos Criollos Casanare En El Municipio de Arauca. Actas Iberoam. Conserv. Anim. AICA 2013, 3, 59-64. 
14. Jáuregui, J.R.; Gutiérrez, C.A.; Cordón, C.L.; Osorio, L.M.; Vásquez, C.L. Determinacion Morfoestructural del Bovino criollo Barroso Salmeco en Guatemala. Actas Iberoam. Conserv. Anim. AICA 2014, 4, 6-8.

15. Parés, P.M. Zoometria. Valoración Morfológica de los Animales Domésticos; Ministerio de Medio Ambiente y Medio Rural y Marino Centro de Publicaciones: Madrid, Spain, 2009. 